\title{
Antibacterial Activities of Mentha piperita L. Extracts Against Bacteria Isolated from Soccer Player's Shoes and its Antioxidant Activities
}

\author{
Ahmet Sadan Okmen*1, Gulten Okmen², Ali Arslan², Mustafa Vurkun² \\ ${ }^{1}$ Department of Basic Education, Class Teacher Department, Mugla Sıtkı Kocman University Education Faculty, Kotekli Mugla 48000, \\ TURKEY \\ ${ }^{2}$ Department of Biology, Mugla Sıtkı Kocman University Faculty of Science, Kotekli Mugla 48000,TURKEY
}

\begin{abstract}
Objective: Microorganisms have an easier entry into the sportsman's epidermis, and these make diseases on athletes. The main scope of the study is to search the lack of information about the biological activities of Mentha piperita extracts against bacteria isolated from soccer player's shoes. Materials and Methods: The bacteria were isolated from soccer player's shoes from Balikesir Spor soccer team after the competition. The plant extracts were tested by disc diffusion assay for antibacterial activity. In addition, the different extracts of plant were screened by ABTS decolorization assay for antioxidant activity. Results: The highest inhibition zone in bacteria were determined on Staphylococcus sp. BFT12 (21 mm). MIC value was determined as $3250 \mu \mathrm{g} / \mathrm{mL}$. The highest antioxidant activity of the plant was determined from aqueous extract of plant. This scavenging activity is about $88 \%$. Discussion/Conclusion: The extracts of the plant have high antibacterial and antioxidant potential.
\end{abstract}

Keywords: Soccer Player, Bacteria, Medicinal Plant, Mentha, Antibacterial Activity, Antioxidant Activity.

\section{INTRODUCTION}

Microorganisms have an easier entry into the athlete's epidermis because skin has a suitable ground for bacterial growth., ${ }^{1,2}$ The microorganisms mostly attacks the feet because shoes create a warm, dark, and moist medium for bacterial improvement. Staphylococcus aureus is a kind of bacteria widely be found to on the skin. ${ }^{3,4}$ This kind of bacteria is the wide reason of many skin infections amongst athletes. These infections can be diffuse through direct or indirect contact with contaminated individuals. Direct contact with an contaminated individual is almost always the reason for Staphylococ infection. Indirect incurring to this infection can hold via handling infected sports equipment or objects.

Skin infections part of $\% 10$ percent of time-loss injuries in some sports and can reason important illness. Skin infections can be diffuse from an athlete to other. Antibiotic-resistant bacteria cause skin infection outbreaks, especially in team sports. Nowadays antibiotic-resistant bacteria constitute a important health threat. ${ }^{75}$ Since 2002, wrestling, volleyball and sports teams in most frequent leather infections caused by antibiotic-resistant bacteria, including the football team outbreaks were reported..$^{5-7}$ The clinical effectiveness of many existing antibiotics are threatened by the emergence of multidrug-resistant pathogens rapidly. ${ }^{8}$

Medical plants are rich sources of agents. These plants used medically in various lands are resource of much potent agents. ${ }^{9,79}$ According to World Health Organization, medicinal plants would be the very important resource to pro-
DOI: 10.5530/ijper.51.3s.5 Correspondence: Ahmet Sadan Okmen, Department of Basic Education, Class Teacher Department, Mugla Sitki Kocman University Education Faculty, Kotekli Mugla 48000 , TURKEY

Phone no: +90 2522111469 E-mail: sadanokmen@gmail. com

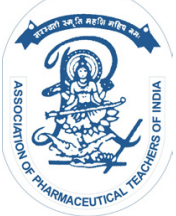

www.ijper.org 
vide a variety of drugs. Also, these plants should be searched to better understand their features, efficacy and safety. ${ }^{10}$ Many plants have been used due to their antimicrobial activities. ${ }^{76}$

Peppermint (Mentha piperita L.), an aromatic plant of the Lamiaceae family, produces an essential oil rich in menthone (14- $32 \%$ ) and menthol (30- 50\%). ${ }^{11}$ Mentha is $50-90 \mathrm{~cm}$ high. This plant is used for allaying various diseases. The leaves of peppermint are commonly used as tea and flavoring. The plant essential oil is used many industry. It is also reported to possess antimicrobial, antiviral, antioxidant and anti-aging properties. ${ }^{11-15,77}$

The biological activities of Mentha plant extracts against Staphylococcus species isolated from athlete's shoes has not been studied. In this study, Mentha piperita growing in Turkey was evaluated for antibacterial and antioxidant activities. The present study were aimed to detect the in vitro biological activities of different extracts of Mentha piperita against Staphylococci.

\section{MATERIAL AND METHODS Organisms}

In this study, test bacteria obtained from previous studies by Dr. Ahmet Sadan Okmen, University of Mugla Sitk1 Kocman, TURKEY (Project number: 14/ 052). The extracts were individually tested against bacteria that Gram-positive bacteria isolated from athlete's shoes. Bacterial identities were made by traditionally techniques by Dr. Gulten OKMEN. ${ }^{16,17}$ Six bacteria were used in this study. All of bacteria are Gram-positive cocci. The bacteria were incubated in Mueller- Hinton Broth for $24 \mathrm{~h}$ at $37^{\circ} \mathrm{C}$ (MHB; Merck). ${ }^{18}$

\section{Plant materials}

Mentha piperita leaves were obtained in February 2017 from Akhtar in Mugla. The identity of plant was diagnosed by Dr. Olcay Ceylan, University of Mugla Sitk1 Kocman. The voucher specimens were stored at herbarium (Herb no: MUH1254) of Biology Department. The identity of this plant was made according to the Flora of Turkey. ${ }^{19}$

\section{Plant extraction}

The leaves of Mentha piperita were washed 2-3 times with running water and sterile distilled water. These materials were air-dried, and then were pulverized in a agitator. The specimens were stocked at $4^{\circ} \mathrm{C}$ until required for analysis. Then the samples $(50 \mathrm{~g})$ were extracted with solvents $(250 \mathrm{~mL})$ using the Soxhlet. In this study was used methanol, ethanol and water as solvent. Extraction process was proceeded for 4 hs. All of extracts were evaporated. After this the extracts were dissolved in their solvent. These extracts kept in small sterile opac bottles under refrigerator temperature until the experiments.

\section{Antibacterial activity assay}

The extract samples were individually tried against Gram-positive bacteria that isolated from athlete's shoes. The plant extracts were tested by disc diffusion method for antibacterial activity. ${ }^{20}$ The concentration and quantity of plant extracts are $25 \mu \mathrm{L}$ of $250 \mathrm{mg} / \mathrm{mL}$. Solvents are methanol, ethanol and aqueous. Solvents are negative control. The bacteria were grown on MuellerHinton agar plates (MHA, Merck) at $37^{\circ} \mathrm{C}$ and the cultures set to $0.5 \mathrm{McF}$ arland. The growth of bacteria were provided at $37^{\circ} \mathrm{C}$ in $24 \mathrm{~h}$. The formed inhibition zones were measured as $\mathrm{mm}$. The antibiotics in study are novobiocin $(30 \mu \mathrm{g})$ and oxacillin $(5 \mu \mathrm{g})$, and that were used as positive control.

\section{Determination of minimum inhibitory concentration (MIC)}

In this study, the MIC values of leaf extracts were found for antibacterial activity. The broth dilution method was done according to CLSI standards. ${ }^{21,22}$ In our study, final concentrations of extracts were 13000, 6500, 3250, 1625 , and $812.5 \mu \mathrm{g} / \mathrm{mL}$.

\section{Non-enzymatic antioxidant activity assay}

These experiments were done by ABTS scavenging activity. ${ }^{23}$ The stock solutions contained ABTS $\bullet+$ solution (7 mM) [2,2'-azino-bis(3-ethylbenzothiazoline-6-sulfonic acid)] and potassium persulfate $(2.45 \mathrm{mM})$ solution. These solutions mixed in equal quantities and that allowed to react for $12 \mathrm{~h}$ at ambient temperature. The scavenging activities of extracts were made according to Re et al. ${ }^{23}$ Then the absorbances were taken spectrophotometric method at $734 \mathrm{~nm}$ (Shimadzu UV-1201V, Japan). Trolox is reference standard of this study (6-hydroxy-2,5,7,8-tetramethychroman- 2-carboxylic acid; Sigma). Results obtained from study were given as $\mathrm{mM}$ Trolox equivalents (TE)/g dry mass.

\section{RESULTS}

The biological activities of plant extracts were made against 6 Staphylococcus sp.-BFT isolates in vitro conditions. The results obtained from this study are given in Table 1. The highest inhibition zone was determined on Staphylococcus sp.-BFT12 for aqueous extract, and this zone is $21 \mathrm{~mm}$. The ethanol extracts were inhibited growth of bacteria and the inhibition zones were between 7- $16 \mathrm{~mm}$. Also antibacterial effects of two extracts used against bacteria absent. These bacteria 
Table 1: Antibacterial activities of Mentha piperita extracts against bacteria isolated from athlete's shoes

\begin{tabular}{|c|c|c|c|c|c|c|c|c|}
\hline \multirow[b]{3}{*}{ Bacteria } & \multicolumn{8}{|c|}{ Inhibition zone diameters (mm) } \\
\hline & \multicolumn{3}{|c|}{ Extracts } & \multicolumn{2}{|c|}{ Antibiotics } & \multicolumn{3}{|c|}{ Solvents } \\
\hline & & & & & & $E$ & $M$ & A \\
\hline & $E$ & M & $A$ & $\mathrm{~N}$ & O & $(25 \mu \mathrm{L})$ & $(25 \mu \mathrm{L})$ & $(25 \mu \mathrm{L})$ \\
\hline $\begin{array}{c}\text { Staphylococcus sp. } \\
\text { BFT8 }\end{array}$ & 9 & 10 & $(-)$ & 34 & 17 & $(-)$ & $(-)$ & $(-)$ \\
\hline $\begin{array}{c}\text { Staphylococcus sp. } \\
\text { BFT9 }\end{array}$ & 9 & 9 & 14 & 28 & 20 & $(-)$ & $(-)$ & $(-)$ \\
\hline $\begin{array}{c}\text { Staphylococcus sp. } \\
\text { BFT12 }\end{array}$ & 16 & 20 & 21 & 34 & 25 & $(-)$ & $(-)$ & $(-)$ \\
\hline $\begin{array}{c}\text { Staphylococcus sp. } \\
\text { BFT23 }\end{array}$ & 16 & 14 & 14 & 46 & 26 & $(-)$ & $(-)$ & $(-)$ \\
\hline $\begin{array}{c}\text { Staphylococcus sp. } \\
\text { BFT28 }\end{array}$ & 7 & $(-)$ & $(-)$ & 36 & 30 & $(-)$ & $(-)$ & $(-)$ \\
\hline
\end{tabular}

Table 2: Minimum inhibitory concentrations of Mentha piperita extracts $(\mu \mathrm{g} / \mathrm{mL})$

\begin{tabular}{|c|c|c|c|}
\hline Bacteria & Ethanol & Methanol & Aqueous \\
\hline Staphylococcus sp. BFT8 & 3250 & 6500 & $(\mathrm{nt})$ \\
\hline Staphylococcus sp. BFT9 & 6500 & 6500 & $(-)$ \\
\hline Staphylococcus sp. BFT10 & 3250 & 6500 & $(-)$ \\
\hline Staphylococcus sp. BFT12 & 3250 & 3250 & $(-)$ \\
\hline Staphylococcus sp. BFT23 & 3250 & 6500 & $(-)$ \\
\hline Staphylococcus sp. BFT28 & 3250 & $(-)$ & $(\mathrm{nt})$ \\
\hline
\end{tabular}

(-): no inhibition (nt): not determined

Table 3: Non-enzymatic antioxidant activities of Mentha piperita extracts $(250 \mathrm{mg} / \mathrm{mL})$

\begin{tabular}{|c|c|c|c|c|c|}
\hline \multicolumn{2}{|c|}{ Ethanol } & \multicolumn{2}{c|}{ Methanol } & \multicolumn{2}{c|}{ Aqueous } \\
\hline TE & Scavenging activity (\%) & TE & Scavenging activity (\%) & TE & Scavenging activity (\%) \\
\hline 2.4 & 79 & 1.7 & 26 & 2.5 & 88 \\
\hline
\end{tabular}

TE: $\mathrm{mM}$ Trolox equivalents (TE)/g dry mass

are resistant to extracts. The lowest inhibition zone was measured as $7 \mathrm{~mm}$. Antibiotics and solvents were used as control.

Another biological activity test is MIC, and broth dilution method was used in this test. MIC values belong to plant leaf extracts were given in Table 2. In our study, the extracts were used from 13000 to $812.5 \mu \mathrm{g} / \mathrm{mL}$ for MIC studies. A lot of bacteria have shown the lowest sensitivity to Mentha piperita leaf ethanol extract. Minimal inhibitory concentration of this extract was determined as $3250 \mu \mathrm{g} / \mathrm{mL}$.

The antioxidant capacities of plant leaves were screened by ABTS scavenging activity. The results of ABTS scavenging studies are provided in Table 3. The results were given as percent ABTS, and trolox were used as reference. The aqueous extract of plant leaves shown $88 \%$ ABTS scavenging capacity at $250 \mathrm{mg} / \mathrm{mL}$ concentration. The antioxidant activities of plant extracts were in the order of Mentha piperita (aqueous) >Mentha piperita (ethanol) $>$ Mentha piperita (methanol) (Table 3).

\section{DISCUSSION}

Nowadays, antibiotic resistance of pathogens increased and it's undesirable side effects of antibiotics. Researchers were suggested the use of plant extracts as antibiotics or alternatives for the treatment of various infectious diseases. In vitro antimicrobial potential of the three extracts from Mentha was assessed quantitatively by Kirby- Bauer method.

The highest inhibition zone was found against Staphylococcus sp.-BFT12 for Mentha piperita aqueous extract. This zone was $21 \mathrm{~mm}$ (Table 1). Antimicrobial activities of peppermint oils have also been previously investigated by different groups. ${ }^{24-32}$ The presence of some of the 
secondary metabolites reported by the earlier workers from the leaves such as eudesmanoids, isoflavone glycosides and essential oils may be the cause of the antibacterial activity of this plant. ${ }^{33,34}$ It is evident from the literature that the phenols, tannins, terpenoids, flavonoids and flavonoid glycosides are active against a wide range of microbes. ${ }^{35-39}$ Some researchers had posted that both Gram positive bacterial species tested were sensitive to peppermint essential oil with the inhibition zone 17 and $13 \mathrm{~mm}$, respectively. ${ }^{40}$ There is evidence in the literature that Gram-positive bacteria are more sensitive to plant oil and extracts than Gram-negative bacteria. ${ }^{41-43}$ The effect of components of essential oil on cell membrane integrity of Gram positive and Gram negative bacteria has been previously reported. ${ }^{44-45,78}$ In Gram-positive bacteria, volatile oil and hydrophobic components may contact directly with the phospholipid bilayer of the cell membrane. Some researchers reported that these components cause increase in ion permeability, leakage of vital intracellular constituents or impairment of the bacterial enzyme systems. ${ }^{46,47}$ Foregoing reports also discussed the antibacterial activity of the mint essential oils against S. aureus, E. coli and Klebsiella spp. ${ }^{48-50} M$. piperita essential oils contained monoterpenes and oxygenated terpenes. ${ }^{51}$ Earlier studies report that the presence of active monoterpene constituents, such as $b$-pinene has the membrane damaging effects on microbes. ${ }^{52}$ Mahboubi and Haghi examined the antibacterial effect of $M$. spicata essential oil by broth microdilution and disk diffusion methods and reported that the essential oil had high antibacterial activity against $S$. aureus, and other bacteria..$^{53}$ The mechanism of antibacterial activity of carvone is not completely understood in great detail. It has been demonstrated that the mechanism of action of carvone on the growth microorganisms includes the destabilization of the phospholipid bilayer structure, interaction with membrane enzymes and proteins, and its act as a proton exchanger reducing the $\mathrm{pH}$ gradient across the membrane..$^{54}$ These reports also supports the our results. According to present study, the plant extracts owned antibacterial activity, and showed minimal inhibitory concentration at $3250 \mu \mathrm{g} / \mathrm{mL}$ (Table 2). Iscan et al. tested peppermint oil and its components menthol and menthone against 21 human and plant pathogens and found moderate inhibitory activity against the human pathogens. ${ }^{55}$ Staphylococcus aureus was inhibited by $0.63 \mathrm{mg} / \mathrm{mL}$ of oil. The differences in the biological activities with the related one may be due to different geographical region, age of the plant, various method followed for extraction of oil, plant variety, seasonal conditions etc. Previous studies of Arbutus pavarini reported that methanolic extract of plant demonstrated $20 \mathrm{~mm}$ as inhibition zone and the MIC value is $4.86 \mathrm{mg} / \mathrm{mL}{ }^{56}$ Whereas, MIC value was measured as $3250 \mu \mathrm{g} / \mathrm{mL}$ in our study, and it is showed that our MIC results are better than results of other investigators. ${ }^{56,57}$

Excessive production of free radicals has been caused damage to biological materials, caused physiological and pathological abnormalities, and various diseases. ${ }^{58-61}$ The results obtained from antioxidant activity of plant extracts are summarized in Table 3. Mentha piperita aqueous extract disclosed $88 \%$ inhibition at $250 \mathrm{mg} / \mathrm{mL}$ (Table 3). Chloroform extract and peppermint oil showed almost equal antioxidant potency (about $90 \%$ ). ${ }^{40}$ It is clear from the data that the concentration of $150 \mathrm{ppm}$ of Mentha piperita essential oil gave a percentage inhibition of DPPH $(81 \pm 1.2 \%)$ nearly of the same concentration of vitamin $C$ which was $90 \pm 1.8 \% .^{51}$ The most powerful scavenging compounds were reported to be monoterpene ketones and 1,8-cineole. ${ }^{62}$ The former investigations reported that $M$. piperita oil composition are found menthol and menthone as major compounds. ${ }^{63-70}$ The diversity in antioxidant capacities with the reported that one may be attributed to different procedures followed or a different geographical environment, plant type, seasonality, physiological age of the plant, and the method of oil isolation..$^{40}$ The antioxidant capacity of mints greatly depends on the presence of phenolics compounds. The major phenolic constituents of mints especially contained that rosmarinic acid and flavonoids. ${ }^{71,72}$ Researchers were determined both flavonoid content and total phenolic content in this plant. ${ }^{73}$ Thus, the biological activities of mint species oils are originated from presence of phenolics and alkaloids. A correlative relationship has been reported between the phytochemicals such as tannins and flavanoids and the free radical scavenging activity and antibacterial activity. ${ }^{74}$ Our results are in concert with the results of various researches.

\section{CONCLUSION}

In conclusion, medical plants might be considered as precursors for antimicrobial and antioxidants drugs. Our study results suggested that Mentha piperita has significant antibacterial activity and it could be many useful in the detection of novel agents of plant origin. In antioxidant activity study, Mentha piperita aqueous extracts can be considered good source of natural compounds with significant antioxidant activity. The present study result proved that the Mentha piperita can be used as a potential source of antibacterial and antioxidant compounds. Therefore it is essential to research farther by the identification of biologically active compounds, 
characterization and purification of the extracts of this plant. Mentha piperita leaves could be a possible alternative to chemicals as it can be harnessed as antibacterial, antioxidant and flavouring agent as spice.

\section{ACKNOWLEDGEMENT}

I express my thanks to Assoc. Prof. Dr. Ibrahim Erdemir (Balıkesir University, School of Physical Education and Sports) and Dr. Olcay Ceylan (University of Mugla Sitki Kocman, Department of Biology).

\section{CONFLICT OF INTEREST}

None

\section{ABBREVIATION USED}

CLSI: Clinical and Laboratory Standards Institute; MIC: Minimum inhibitory concentration; ABTS: 2,2'-azinobis(3-ethyl benzothiazoline-6-sulfonic acid); TE: Trolox equivalent; MHA: Mueller-Hinton Agar; DPPH: 2,2-diphenyl-1-picrylhydrazyl; h: hour; $\mathrm{mg} / \mathrm{mL}$ : milligram/milliliters; ug/mL: microgram/milliliters; $\mathrm{nm}$ : nanometer; ${ }^{\circ} \mathrm{C}$ : Celsius degree; $\mathrm{mm}$ : millimeter.

\section{REFERENCES}

1. Adams BB. Adolescent medicine: state of the art reviews. Sports Derm. 2001;12:305-22.

2. Adams BB. Sports dermatology. Springer: New York; 2006.

3. Powell FC. Sports dermatology. J Eur Acad Dermatol Venerol. 1994;3(1):1-15.

4. Adams BB. Dermatologic disorders of the athlete. Sports Med. 2002;32(5):309-21.

5. CDC. Centers for Disease Control. Staphylococcal infections in wrestlers: lowa. MMWR Morb Mortal Wkly Rep. 1962;11:152.

6. Decker MD, Lybarger JA, Vaughn WK, Hutcheson RH, Schaffner W. An outbreak of Staphylococcal skin infections among river rafting guides. Am J Epidemiol. 1986;124(6):969-76.

7. Nguyen DM, Mascola L, Brancoft E. Recurring methicillin-resistant Staphylococcus aureus infections in a football team. Emerg Infect Dis. 2005;11(4):526-32.

8. Penner RFR, Madsen KL. Probiotics and nutraceuticals: non-medicinal treatments of gastrointestinal diseases. Curr Opin Pharmacol. 2005;5(6):596-603.

9. Srivastava J, Lambert J, Vietmeyer N. Medicinal plants: An expanding role in development. World Bank Technical Paper:Washington; paper number 320. 1996.

10. Nascimento GGF, Lacatelli J, Freitas PC, Silva GL. Antibacterial activity of plant extracts and phytochemicals on antibiotic-resistant bacteria. Braz $J$ Microbiol. 2000;31:886-91.

11. Rodrigues CR, Faquin V, Trevisan D, Pinto JEBP, Bertolucci SKV, Rodrigues TM. Mineral nutrition, growth and essential oil content of mint in nutrient solution under different phosphorus concentrations. Hortic Bras. 2004;22(3):573-8.

12. Ali MA, Saleem M, Ahmad W, Parvez M, Yamdagni R. A chlorinated monoterpene ketone, acylated-sitosterol glycosides and a flavanone glycoside from Mentha longifolia (Lamiaceae). Phytochemistry. 2002;59(8):889-95.

13. Singh CS, Agarwal R. Evaluation of antibacterial activity of volatile oil from Mentha spicata L. JDDT. 2013;3(4):120-21.

14. Burt S. Essential oils: their antibacterial proprieties and potential application in food. Int J Food Microbiol. 2004;94(3):223-53.
15. Kordali S, Kotan R, Mavi A, Cakir A, Ala A, Yildirim A. Determination of the chemical composition and antioxidant activity of the essential oil of Artemisia dracunculus and of the antifungal and antibacterial activities of Turkish Artemisia absinthium, A dracunculus, Artemisia santonicum and Artemisia spicigera essential oils. J Agric Food Chem. 2005;53(24):9452-8.

16. Cowan ST, Steel KJ. Manual for the identification of medical bacteria. Cambridge University Press:London; 1965.

17. Monica C. Medical laboratory manual for Tropical countries. Cambridge University Press:UK; 1991.

18. Okmen AS. Antioxidant and antibacterial activities of different plants extracts against Staphylococcus aureus isolated from soccer player's shoes and knowledge and applications about foot hygiene of the soccer players. Afr J Tradit Complement Altern Med. 2015;12(3):143-9.

19. Davis PH. Flora of Turkey and The East Aegaean Islands. Edinburgh University Press:Edinburgh; 1975.

20. Bauer AW, Kirby WM, Sherris JC, Turck M. Antibiotic susceptibility testing by a standardized single disk method. Am J Clin Path. 1966;45(4):493-6.

21. CLSI (Clinical and Laboratory Standards Institute); Methods for Dilution Antimicrobial Susceptibility Test for Bacteria that Grow Aerobically, Approved Standard M7-A $6^{\text {th }}$ edn: National Committee for Clinical Laboratory Standards; Philadelphia;Wayne. 2003.

22. CLSI (Clinical and Laboratory Standards Institute); Performance Standards for Antimicrobial Susceptibility Testing, $16^{\text {th }}$ Informational Supplement M100-S16: National Committee for Clinical Laboratory Standards; Philadelphia;Wayne. 2006.

23. Re R, Pellegrini N, Protrggente A, Pannala A, Yang M, Rice-Evans C. Antioxidant activity applying an improved ABTS radical cation decolorization assay. Free Radical Biol Med. 1999;26(9):1231-7.

24. Hendriks H. Pharmaceutical aspects of some Mentha herbs and their essential oils. Perfum Flavor. 1998;23:15-23.

25. Cowan MM. Plant products as antimicrobial agents. Clin Microbiol Rev. 1999;12(4):564-82.

26. Hammer KA, Carson JF, Riley TV. Antimicrobial activity of essential oils and other plant extracts. J Appl Microbiol. 1999;86(6):985-90.

27. Delespaul Q, Billereck BG, Roques CG, Michel G, Vinuales CM, Bessiere JM. The antifungal activity of essential oils as determined by screening methods. J Essent Oil Res. 2000;12(2):256-66.

28. Pattnaik S, Subramanyam VR, Bapaji M, Kole CR. Antibacterial and antifungal activity of aromatic constituents of essential oils. Microbios. 1997;89(358):39-46

29. Hammer KA, Carson JF, Riley TV. In vitro activity of essential oils, in particular Melaleuca alternifolia (tea tree) oil and tea tree oil products, Candida spp. J Antimicrob Chemoth. 1998;42(5):591-5.

30. Sivropoulou A, Kokkini S, Lanaras T. Antimicrobial activity of mint essential oils. J Agric Food Chem. 1995;43(9):2384-8.

31. Tassou C, Koutsoumanis K, Nychas GJE. Inhibition of Salmonella Enteritidis and Staphylococcus aureus in nutrient broth by mint essential oils. Food Res Int. 2000;33(3):273- 80.

32. Baruah P, Sharma RK, Singh RS, Ghosh AC. Fungicidal activity of some naturally occurring essential oils against Fusarium moniliforme. J Essent Oil Res. 1996;8(4):411-3.

33. Prasad PP, Sawaikar DO, Rojatkar SR, Nagasampagi BA. Eudesmanoids from Sphaeranthus indicus. Fitoterapia. 2000;71(3):264-8.

34. Shekhani MS, Shah PM, Yasmin A, Siddiqui R, Perveen S, Khan KM, Kazmia SU, Atta-Ur-Rahman. An immunostimulant sesquiterpene glycoside from Sphaeranthus indicus. Phytochemistry. 1990;29(8):2573-6.

35. Mason TL, Wasserman BP. Inactivation of red beet betaglucan synthase by native and oxidized phenolic compounds. Phytochemistry. 1987;26(8):2197-202.

36. Scalbert A. Antimicrobial properties of tannins. Phytochemistry. 1991;30(12):3875-83.

37. Jones GA, Mc Allister TA, Muir AD, Cheng KJ. Effects of sainfoin (Onobrychis viciifolia scop.) condensed tannins on growth and proteolysis by four strains of ruminal bacteria. Appl Environ Microbiol. 1994;60(4):1374-8.

38. Scortichini M, Pia Rossi M. Preliminary in vitro evaluation of the antimicrobial activity of terpens and terpenoids towards Erwinia amylovora (Burrill). J Appl Bacterial. 1991;71(2):109- 12.

39. Tsuchiya H, Sato M, Miyazaki T, Fujiwara S, Tanigaki S, Ohyama M, Tanaka $\mathrm{T}$, Linuma M. Comparative study on the antibacterial activity of phytochemical 
flavanones against methicillin-resistant Staphylococcus aureus. J Ethnopharmacol. 1996;50(1):27-34.

40. Singh R, Shushni MAM, Belkheir A. Antibacterial and antioxidant activities of Mentha piperita L. Arab J Chem. 2015;8(3):322-8.

41. Cosentino S, Tuberoso CIG, Pisano B, Satta M, Mascia V, Arzedi E, et al. In vitro antimicrobial activity and chemical composition of Sardinian Thymus essential oils. Lett Appl Microbiol. 1999;29(2):130-5.

42. Karaman I, Sahin F, Gulluce M, Ogutcu H, Sengul M, Adiguzel A. Antimicrobial activity of aqueous and methanol extracts of Juniperus oxycedrus L. J Ethnopharmacol. 2003;85(2):231-5.

43. Sahin F, Karaman I, Gulluce M, Ogutcu H, Sengul M, Adiguzel A, et al. Evaluation of antimicrobial activities Satureja hortensis L. J Ethnopharmacol. 2002;87(1):61-5.

44. Cox SD, Mann CM, Markham JL, Bell HC, Gustafson JE, Warmington JR. The mode of antimicrobial action of the essential oil of Melaleuca alternifolia (tea tree oil). J Appl Microbiol. 2000;88(1):170-5.

45. Oussalah M, Caillet S, Lacroix M. Mechanism of action of Spanish oregano, Chinese cinnamon, and savory essential oils against cell membranes and walls of Escherichia coli O157:H7 and Listeria monocytogenes. J Food Prot. 2006;69(5):1046-55.

46. Ratledge C, Wilkinson SG. An Overview of Microbial Lipids. In: Ratledge C, Wilkinson SG, editors. Microbial lipids. London:Academic Press; 1988.

47. Wendakoon $\mathrm{CN}$, Sakaguchi M. Inhibition of amino acid decarboxylase activity of Enterobacter aerogenes by active components in spices. J Food Prot. 1995;58(3):280-3.

48. Jeyakumar E, Lawrence R, Pal T. Comparative evaluation in the efficacy of peppermint (Mentha piperita) oil with standards antibiotics against selected bacterial pathogens. Asian Pac J Trop Biomed. 2011;1(2):253-7.

49. Sujana $P$, Sridhar $T$, Josthna $P$, Naid CV. Antibacterial activity and phytochemical analysis of Mentha piperita L. (Peppermint) - An important multipurpose medicinal plant. AJPS. 2013;4(01):77-83.

50. Singh CS, Agarwal R. Evaluation of antibacterial activity of volatile oil from Mentha spicata L. JDDT. 2013;3(4):120-1.

51. Derwich E, Chabir R, Taouil R, Senhaji O. In vitro antioxidant activity and GC/MS studies on the leaves of Mentha piperita (Lamiaceae) from Morocco. IJPSDR. 2011;3(2):130-6.

52. Sikkema J, Debont JAM, Poolman B. Mechanisms of membrane toxicity of hydrocarbons. Microbiol Rev. 1995;59(2):201-22.

53. Mahboubi M, Haghi G. Antimicrobial activity and chemical composition of Mentha pulegium L. essential oil. J Ethnopharmacol. 2008;119(2)325-7.

54. Aggarwal KK, Khanuja SPS, Ahmad A, Kumar TRS, Gupta VK, Kumar S. Antimicrobial activity profiles of the two enantiomers of limonene and carvone isolated from the oils of Mentha spicata and Anethum sowa. Flavour Frag J. 2002;17(1):59-63.

55. Iscan G, Kirimer N, Kurkcuoglu M, Baser KH, Demirci F. Antimicrobial screening of Mentha piperita essential oils. J Agr Food Chem. 2002;50(14):3943-6.

56. Alsabri SG, El-Basir HM, Rmeli NB, Mohamed SB, Allafi AA, Zetrini AA, Salem AA, Mohamed SS, Gbaj A, El-Baseir MM. Phytochemical screening, antioxidant, antimicrobial and anti-proliferative activities study of Arbutus pavarii plant. J Chem Pharma Res. 2013;5(1):32-6.

57. Sharma N, Maiti SK, Koley KM. Studies on the incidence of subclinical mastitis in buffaloes of Rajnandgaon district of Chhattisgarh State.Vet Practitioner. 2004;5(2):123-4.

58. Sakanaka S, Tachibana Y, Okada Y. Preparation and antioxidant properties of extracts of Japanese persimmon leaf tea (kakinoha-cha). Food Chem. 2005;89(4):569-75.
59. Alothman M, Bhat R, Karim AA. Antioxidant capacity and phenolic content of selected tropical fruits from Malaysia, extracted with different solvents. Food Chem. 2009;115(3):785-8.

60. Hasan M, Alam MN, Wahed TB, Sultana F, Jamiuddin A. In vitro antioxidant potential of the methanolic extract of Bacopa monnieri L.Turk J Pharm Sci. 2012;9(3):285-92.

61. Keser S, Celik S, Turkoglu S, Yilmaz O, Turkoglu I. Hydrogen peroxide radical scavenging and total antioxidant activity of hawthorn. Chem J. 2012;2(1):9-12.

62. Mimica-Dukic N, Bozin B, Sokovic M, Mihajlovic B, Matavulj M. Antimicrobial and antioxidant activities of three Mentha species essential oils. Planta Med. 2003;69(05):413-9.

63. Lawrence BM. Progress in essential oils: Peppermint oil. Perfum Flavor. 1997;22(5):57-66.

64. Gerherman C, Julea M, Cozar O. Comparative analysis of some active principles of herb plants by GC/MS. Talanta. 2000;53(1):253-62.

65. Aflatuni A, Heikkinen K, Tomperry P, Jalonen J, Laine K. Variation in the extract composition of mints of different origin cultivated in Finland. J Essent Oil Res. 2000;12(4):462-6.

66. Stojanova A, Paraskevova P, Anastassov $\mathrm{CH}$. A comparative investigation on the essential oil composition of two Bulgarian cultivars of Mentha piperita L. J Essent Oil Res. 2000;12(4):438-40.

67. Maffei M. Sustainable methods for a sustainable production of peppermint (Mentha piperita L.) essential oil. J Essent Oil Res. 1999;11(3):267-82.

68. Rohloff J. Monoterpene composition of essential oil from peppermint (Mentha piperita L.) with regard to leaf composition using solid-phase microextraction and GC/MS analysis. J Agric Food Chem. 1999;47(9):3782-6.

69. Chalchat JC, Garry RP, Michet A. Variation of chemical composition of essential oil of Mentha piperita L. during the growing time. J Essent Oil Res. 1997;9(4):463-5.

70. Spencer JS, Dowd E, Faas W. The genuineness of two mint essential oils. Perfum Flavor. 1997;22(3):37-45.

71. Janicsak G, Mathe I, Miklossy-Vari V, Blunden G. Comparative studies of the rosmarinic and caffeic acid contents of Lamiaceae species. Biochem Syst Ecol. 1999;27(7):733-8.

72. Areias FM, Valentao P, Andrade PB, Ferreres F, Seabra RM. Phenolic fingerprint of peppermint leaves. Food Chem. 2001;73(3):307-11.

73. Naidu JR, Ismail RB, Yeng C, Sasidaran S, Kumar P. Chemical composition and antioxidant activity of the crude methanolic extracts of Mentha spicata. J. Phytol. 2012;4(1):13-8.

74. Kaur J, Xavier R, Marimuthu K, Leng KM, Rajasekaran A, Kathiresan S, Sreeramanan S. Preliminary investigation on the antibacterial activity of mango (Mangifera indica L: Anacardiaceae) seed kernel. Asian Pac J Trop Med. 2010;3(9):707-10.

75. Sharafi SM, Rasooli I, Owlia P, Taghizadeh M, Astaneh SDA. Protective effects of bioactive phytochemicals from Mentha piperita with multiple health potentials. Pharmacognosy Magazine. 2010;6 (23):147-53.

76. Rachitha P, Krupashree K, Jayashree GV, Gopalan N, Khanum F. Growth inhibition and morphological alteration of Fusarium sporotrichioides by Mentha piperita essential oil. Pharmacognosy Magazine. 2017;9(1):74-9.

77. Sim KS, Sri Nurestri AM, Norhanom AW. Phenolic content and antioxidant activity of Pereskia grandifolia Haw. (Cactaceae) extracts. Pharmacognosy Magazine. 2010;6(23):248-54.

78. Veras HNH, Campos AR, Rodrigues FFG, Botelho MA, Coutinho HDM, Menezes IRA, daCosta JGM. Enhancement of the antibiotic activity of erythromycin by volatile compounds of Lippia alba (Mill.) N.E. Brown against Staphylococcus aureus. Pharmacognosy Magazine. 2011;7(28):334-7.

79. Johri RK. Cuminum cyminum and Carum carvi: An update. Pharmacognosy Magazine. 2011;5(9):63-72. 
PICTORIAL ABSTRACT MIC values of Mentha piperita ethanol extracts

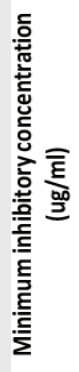

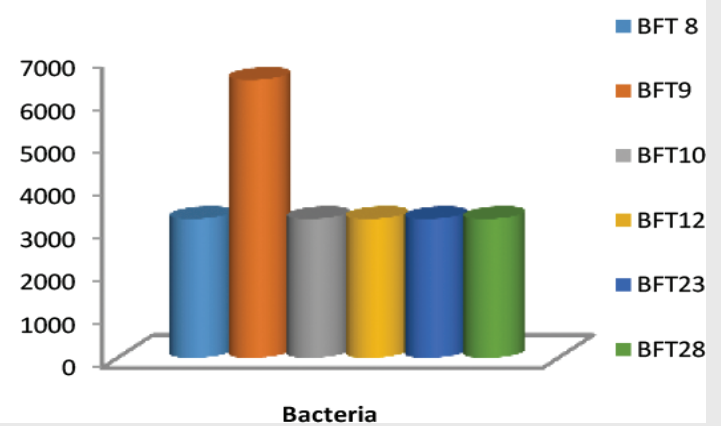

\section{SUMMARY}

- The highest antibacterial activity was determined at aqueous extract for Staphylococcus BFT12. In this study, all of the bacteria were shown sensivity for $3250 \mu \mathrm{g} / \mathrm{mL}$ concentration of this plant. The highest antioxidant activity was shown at aqueous extract. Our results suggest that Mentha piperita has significant antibacterial and antioxidant activity and it could be very useful in the discovery of novel antibacterial and antioxidant agents of plant origin

\section{ABOUT AUTHORS}

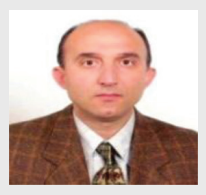

Assist. Prof. Dr. Ahmet Sadan Okmen: He works at the Faculty of Education in Mugla Sitki Kocman University. He is Sports Science Association member. He participated in many meeting and has many publications. He gives many courses at undergraduate and graduate degree. He made Ph D. degree at Ataturk University. He also worked as a reviewer for various national and international journals.

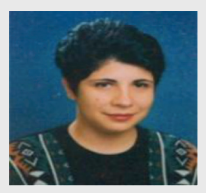

Assoc. Prof. D. Gülten Okmen: She works Mugla Sitki Koçman University in Biology Department. She is member of the European Association of Biotechnology and Biologists Association. She has a lot of scientific meetings and publications. She teaches a lot of curses at the bachelor and graduate degree. She done Ph. D degree at Ankara University, Department of Biology. She is working about Archaeal, Cyanobacterial and Microbial Biotechnology. She also worked as a potential reviewer for various national and international journals.

MSc. Ali Arslan: He is MSc.student in the scope of Microbial Biotechnology at Mugla Sitki Kocman University. He works about Archaea. He has a lot of scientific meetings and article. He is pursuining his MSc. at Mugla Sitki Kocman University.

Msc. Mustafa Vurkun: He is Msc.student at Mugla Sitki Kocman University and works about Microbial Biotechnology. He works about Methicillin resistance Staphylococcus aureus (MRSA). $\mathrm{He}$ has a lot of scientific meetings and article. He is pursuining his MSc. at Mugla Sitki Kocman University.

Cite this article: Okmen AS, Okmen G, Arslan A, Vurkun M. Antibacterial Activities of Mentha piperita L. Extracts Against Bacteria Isolated from Soccer Player's Shoes and its Antioxidant Activities. Indian J of Pharmaceutical Education and Research. 2017;51(3)Suppl:S163-69. 